\title{
Response to Letter to Editor Regarding Article "Rising from Plagiarising” MAOS-D-14-00100R1
}

\author{
Muralee Mohan ${ }^{1} \cdot$ Deepthi Shetty $^{2} \cdot$ Tripthi Shetty $^{1} \cdot$ Kalpa Pandya $^{1}$
}

Received: 1 June 2016/Accepted: 1 September 2016/Published online: 29 September 2016

(C) The Association of Oral and Maxillofacial Surgeons of India 2016

We appreciate the interest shown by Dr. Pathum Sookaromdee in our article "Rising from plagiarising" [1].

The concerns have been expressed regarding:

1. Instilling the values of avoiding plagiarism in the young minds.

2. Combating plagiarism being performed at a higher level by senior professionals in the field.

We recommend the following to address the issue:

1. Simple acts of copying should be curbed at the level of schools and colleges. Value of being original in homework, projects and any work one performs should be taught. If the habit is nipped in the bud, one's moral values will not allow him/her to perform plagiarism.

2. Plagiarism detection softwares should be available readily especially at all academic institutions and universities. Any work whether being published or not should be scrutinized for plagiarism. This will also address the issue of unintended plagiarism among the authors.

3. Senior professionals are pioneers in their fields and act as role models for their junior colleagues and students. Any act of plagiarism by them is unacceptable and strict legal action must be taken in response. In fact, they can have foremost role in attacking plagiarism if they critically appraise the work of their junior colleagues and encourage them to be original rather than doing a forgery.

4. Lastly we reiterate our belief that scientific journals have a major role in fighting plagiarism. Not a single plagiarized article can get published if all the journals whether big or small scrutinize every piece of text for plagiarism before printing.

\section{Compliance with Ethical Standards}

Human or Animal Rights This article does not contain any studies with human or animal participants performed by any of the authors.

Conflict of interest Dr. Muralee Mohan, Dr. Deepthi Shetty, Dr. Tripthi Shetty and Dr. Kalpa Pandya have declared that they have no conflicts of interest.

\section{Reference}

1. Mohan M, Shetty D, Shetty T, Pandya K (2015) Rising from plagiarising. J Maxillofac Oral Surg 14(3):538-540
Kalpa Pandya

kalpa.pandya@gmail.com

1 Department of Oral and Maxillofacial Surgery, A.B. Shetty Memorial Institute of Dental Sciences, Gokul, 3, Tejpal Road, Mumbai 400007, India

2 Department of Oral and Maxillofacial Surgery, S.D.M. Dental College, Dharwad, India 